\title{
NEUROVASCULAR REACTIVITY IN PATIENTS WITH ACUTE ISCHEMIC STROKE
}

\author{
NevZat UZUNER, Gülnur TEKGÖL UZUNER \\ Eskisehir Osmangazi University Faculty of Medicine, \\ Department of Cerebrovascular Diseases, Eskisehir, TURKEY
}

\begin{abstract}
OBJECTIVE: We aimed to assess the motor evoked blood flow velocity (BFV) changes in both middle cerebral arteries (MCA) using transcranial Doppler (TCD) monitoring in patients with acute ischemic strokes and healthy subjects.

METHODS: Eighty-two patients with acute territorial infarction in the MCA territory, 83 patients with acute lacunar infarction in MCA territory and 21 control subjects were investigated. A long term TCD monitoring device was used for the simultaneous recording of both MCA during 10 cycles of 20 seconds while the subjects performed hand gripping with a frequency of one per second, and subsequently 20 seconds when they were resting to assess BFV changes on activated cortical motor areas. Neurovascular reactivity was defined as a relative increase in blood flow velocities which were calculated as the percentage change in baseline value.

RESULTS: Hand gripping showed a marked rise in the blood flow velocities in both MCAs in all subjects ( $p<0.001$ for all vessels). Patients with territorial infarction had significantly lower neurovascular reactivity $(15.0 \% \pm 9.5)$ than those of patients with lacunar infarction $(19.9 \% \pm 11.5 \mathrm{p}<0.007)$.

CONCLUSION: Our results suggest that unilateral cerebrovascular ischemic events can affect blood flow in both MCAs in patients with acute ischemic events in the MCA territory, and neurovascular reactivity was preserved in patients with lacunar stroke in contrast to territorial stroke.

Keywords: Cerebrovascular disease, ischemic stroke, ultrasound, transcranial Doppler sonography, blood flow velocity, reactivity.
\end{abstract}

\section{AKUT İSKEMIK İNMELI HASTALARDA NÖROVASKÜLER REAKTIVITE}

\section{ÖZET}

AMAÇ: Akut iskemik stroklu hastalarda ve sağlıklı kişilerde transkraniyal Doppler ile motor uyarıya karşllı her iki orta serebral arterdeki kan akım hızı değişikliklerini değerlendirmeyi amaçladık.

GEREÇ ve YÖNTEM: MCA alanında akut geniș enfarktı olan 82 hasta, MCA alanında akut laküner enfarktı olan 83 hasta ve 21 sağlıklı kontrol incelendi. Her iki MCA'yı eş zamanlı olarak kayıt etmek için uzun süreli TCD monitorizasyon cihazı kullanıldı. Aktive olan kortikal motor alanlardaki kan akım hızı değișikliklerini değerlendirmek amacı ile hastalar 20 saniye boyunca bir saniyelik aralıklarla yumruk sıktılar ve arkasından 20 saniye dinlendiler. Bu şekilde 10 siklus uygulandı. Nörovasküler reaktivite kan akım hızlarındaki yüzdelik değişim olarak hesaplandı.

BULGULAR: Tüm olgularda her iki MCA'da da yumruk sıkma ile belirgin kan akım hızı artışı gözlendi (tüm damarlar için $\mathrm{p}<0.001)$. MCA alanında geniş enfarktı olan hastalarda nörovasküler reaktivite $(\% 15,0 \pm 9,5)$ laküner enfarktı olan hastalardakinden $(\% 19,9 \pm 11,5)$ anlamlı derecede daha düşüktü $(\mathrm{p}<0,007)$.

SONUÇ: Bulgularımız tek taraflı serebrovasküler iskemik olayların her iki MCA'daki kan akımını etkileyebileceğini ve geniş enfarklı hastaların tersine laküler enfarklı hastalarda nörovasküler reaktivitenin korunduğunu göstermektedir.

Anahtar Sözcükler: Beyin damar hastalıkları, iskemik inme, ultrason, transkraniyal Doppler, kan akım hızı, reaktivite.

\footnotetext{
Corresponding author: Nevzat Uzuner, MD. Eskisehir Osmangazi University Faculty of Medicine, Department of Neurology. Eskisehir, Turkey. Telephone: +90222 $2392979 \quad$ E-mail: nevzatuzuner@gmail.com Received: $10.02 .2016 \quad$ Accepted: 16.02 .2016

This article should be cited as following: Uzuner N, Tekgöl Uzuner G. Neurovascular reactivity in patients with acute ischemic stroke. Turkish Journal of Cerebrovascular Diseases 2016; 22 (1): 9-12. doi:10.5505/tbdhd.2016.04809.
} 


\section{INTRODUCTION}

Transcranial Doppler sonography (TCD) provides information about blood flow velocity (BFV) changes in individual cerebral arteries as a representation of cerebral blood flow to visual stimulation [1, 2]. Moreover, the TCD method can provide temporal information about the dynamics of the response [3]. TCD has usually been used to evaluate visually evoked responses; less motor evoked response has been reported [4-6]. We aimed to assess the motor evoked BFV changes in both middle cerebral arteries (MCAs) using TCD monitoring in patients with acute ischemic strokes and healthy subjects.

\section{MATERIAL AND METHODS}

Consequently, 862 patients with suspected cerebrovascular disease were scanned for the study during 1 year period. Two-hundred-thirtysix patients with hemorrhagic cerebrovascular disease, 168 patients with posterior circulation strokes, 37 patients with cerebral venous thrombosis, 78 patients with transient ischemic attack, 18 patients with another illness (multiple sclerosis, epilepsy, etc.), 18 patients with ischemic stroke in the anterior cerebral artery territory, and 109 patients with ischemic stroke during coma status (less than 9 the Glasgow coma scale) were excluded from the study. The remaining 198 patients with territorial MCA infarctions or lacunar infarctions in the MCA territory that were conscious (more than 8 on the Glasgow coma scale) were included in the study. Twenty-five healthy subjects were reserved as the control for this study. Control subjects had neither active neurological diseases nor histories of neurological disorders and were selected from the voluntary relatives of the patients. All patients had a routine clinical and hematological examination, extracranial Doppler examination, and cranial computed tomography or cranial magnetic resonance imaging was performed on all patients. The confirmation from the local Clinical Research Ethics Committee was received for this study.

A long term TCD monitoring device (Multidop X4 DWL and TCD8 software, Elektronische Systeme $\mathrm{GmbH}$, Sipplingen) was used for the simultaneous recording of both MCAs using bilateral 2-MHz probes that were tightly fixed by a headband. Through the temporal bone both M1 segments of the MCAs (flow direction toward the probe) were insonated at a depth of 48 to $58 \mathrm{~mm}$. The proven MCA insonation was required to increase the flow velocities on both sides for the measurement of motor evoked flow during hand gripping as opposed to resting (Figure 1). All TCD examinations were done within 2 days of the ischemic event. All lesion sides were arranged to the left side and non-lesion sides to the right side in patients.

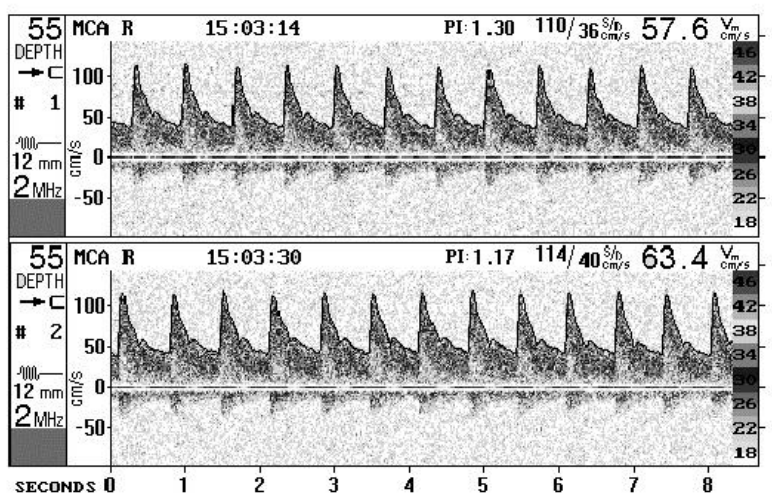

Figure 1. MCA velocity signals are recorded in the M1 segment; the upper spectral recording corresponds to resting and the lower one to hand gripping. Note the increase in the velocities during hand gripping. D indicates insonation depth is given in millimeters $\rightarrow$ [flow direction; PI, pulsatility index; Vm, mean velocity].

All subjects were monitored during 10 cycles of 20 seconds while the subjects performed hand gripping (moving the thumb along the other fingers) with a frequency of one per second, and subsequently 20 seconds when they were resting to assess BFV changes on activated cortical motor areas (Figure 2).

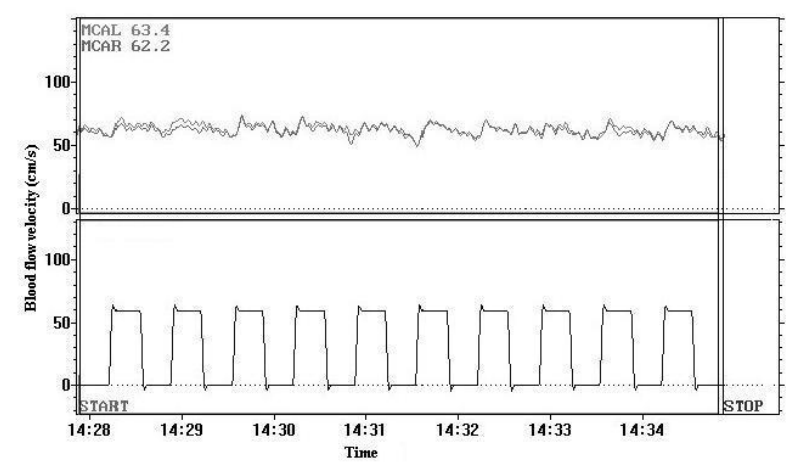

Figure 2. Continuous recordings of BFVs simultaneously in the left and right MCA during 10 cycles. Each cycle consisted of a sequence of rest (20 seconds), followed by hand gripping (20 seconds). Gripping the hands induced a regular increase in the velocities. 
Calculations were performed off-line, and neurovascular reactivity was defined as a relative increase in blood flow velocities which were calculated as the percentage change in baseline value [Neurovascular reactivity $=100^{*}(\mathrm{Vs}-\mathrm{Vr}) / \mathrm{Vr}$ ]. Where Vs means maximum velocity during hand gripping, $\mathrm{Vr}$ indicates the minimum velocity at rest which is calculated by the special software of this system during the procedure as shown in Figure 3.

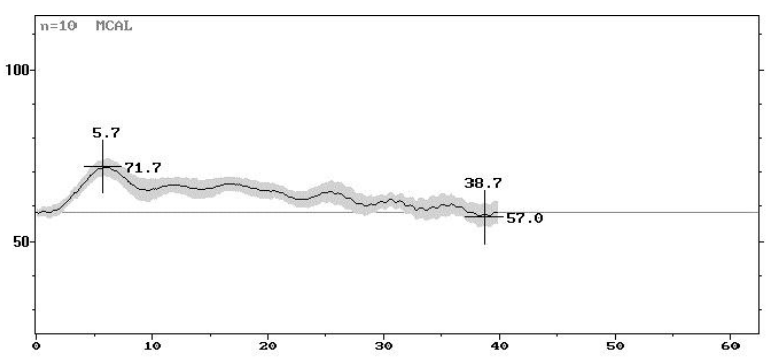

Figure 3. The figures show the waveform of the averaged responses of 10 cycles recorded in the M1 segment of the left MCA during hand gripping and resting in a patient (right) and a control subject (left). The figures show increases in BFVs of MCAs (mean value, the shaded areas indicate $\pm 2 \mathrm{SEM}$ ). The maximum and minimum values were calculated as a single value of stimulation and rest, respectively.

Four control subjects, 18 patients with territorial infarction and 15 patients with lacunar infarction were excluded because of their poor temporal bone resolution. The remaining 82 patients (36 female, 46 male; aged 55.6 \pm 14.9 years) with acute territorial infarction in the MCA territory, 83 patients ( 22 female, 61 male; aged $59.7 \pm 11.6$ years) with acute lacunar infarction in MCA territory and 21 control subjects ( 9 female, 12 male; aged $52.3 \pm 13.1$ years) were included in analysis.
Two-tailed paired t-test, One-way ANOVA, and Kruskal-Wallis (Chi-Square) test were applied to statistical analyzes where appropriate, and $\mathrm{p}<0.05$ was accepted for statistical significance.

\section{RESULTS}

There was no significant age and gender difference between the patients and controls. The summaries of the motor evoked responses are shown in Table 1. The patients were not able to perform bilateral hand gripping because of the hemiparesis as expected. However, hand gripping showed a marked increase in the blood flow velocities in both MCAs in all subjects $(\mathrm{p}<0.001$ for all vessels) without a significant side-to-side difference except for patients with territorial infarction in which there was a significant reduction in neurovascular reactivity on the lesion side when compared with the non-lesion side. Also, patients with territorial infarction had significantly lower neurovascular reactivity $(15.0 \pm 9.5)$ than those of patients with lacunar infarction $(19.9 \pm 11.5, \mathrm{p}<0.007)$. Moreover, mean flow velocities, flow velocities at stimulation and flow velocities at rest were found to be lower on the lesion side in all patients compared with the controls. However, these values were not significant.

Risk factors of the subjects are shown in Table 2. Briefly, hypertension and atrial fibrillation were found to be higher in the patients than in the controls. Other risk factors including diabetes mellitus, coronary artery disease, smoking or alcohol consumption were not significantly different amongst the patients.

Table 1. The motor evoked responses in subjects.

\begin{tabular}{lllllll}
\hline & \multicolumn{2}{l}{ Lesion side or left side } & \multicolumn{3}{l}{ Non-Lesion side or right side } \\
\cline { 2 - 7 } & $\begin{array}{l}\text { Territorial } \\
(\mathrm{n}=82)\end{array}$ & $\begin{array}{l}\text { Lacunar } \\
(\mathrm{n}=83)\end{array}$ & $\begin{array}{l}\text { Control } \\
(\mathrm{n}=21)\end{array}$ & $\begin{array}{l}\text { Territorial } \\
(\mathrm{n}=82)\end{array}$ & $\begin{array}{l}\text { Lacunar } \\
(\mathrm{n}=83)\end{array}$ & $\begin{array}{l}\text { Control } \\
(\mathrm{n}=21)\end{array}$ \\
\cline { 2 - 7 } $\mathrm{Vs}(\mathrm{cm} / \mathrm{sec})$ & $57.7 \pm 19.7$ & $54.9 \pm 16.6$ & $63.4 \pm 17.6$ & $60.2 \pm 18.9$ & $54.9 \pm 14.2$ & $61.2 \pm 19.0$ \\
$\operatorname{Vr}(\mathrm{cm} / \mathrm{sec})$ & $50.4 \pm 17.4$ & $46.0 \pm 13.5$ & $53.4 \pm 15.7$ & $51.0 \pm 16.7$ & $46.2 \pm 12.5$ & $51.2 \pm 16.8$ \\
$\operatorname{Vm}(\mathrm{cm} / \mathrm{sec})$ & $53.6 \pm 18.2$ & $50.1 \pm 14.7$ & $57.5 \pm 16.3$ & $55.3 \pm 17.3$ & $50.4 \pm 13.1$ & $55.3 \pm 17.2$ \\
Reactivity $(\%)$ & $15.0 \pm 9.5^{*}$ & $19.9 \pm 11.5$ & $19.9 \pm 09.4$ & $18.6 \pm 11.6$ & $19.4 \pm 9.0$ & $20.4 \pm 8.3$ \\
\hline
\end{tabular}

Vs indicates velocity at stimulation, Vr indicates velocity at rest, Vm indicates mean velocity; Values are mean \pm SD; One-way ANOVA, ${ }^{*} \mathrm{p}<0.007$ between territorial and lacunar infarction (Post Hoc Tukey test).

Table 2. Risk factors in subjects.

\begin{tabular}{|c|c|c|c|c|}
\hline & Territorial infarction & Lacunar infarction & Control & P value \\
\hline Hypertension & $40(48.8 \%)$ & $51(61.4 \%)$ & $3(14.3 \%)$ & $\mathrm{P}<0.001$ \\
\hline Atrial fibrillation & $20(24.4 \%)$ & $7(8.4 \%)$ & $1(4.8 \%)$ & $\mathrm{P}=0.005$ \\
\hline Diabetes Mellitus & $18(22.0 \%)$ & $16(19.3 \%)$ & $0(0 \%)$ & NS \\
\hline Coronary artery disease & $6(7.3 \%)$ & $10(12.0 \%)$ & $0(0 \%)$ & NS \\
\hline Smoking & $21(25.6 \%)$ & $19(22.9 \%)$ & $8(38.1 \%)$ & NS \\
\hline Alcohol consumption & $12(14.6 \%)$ & $8(9.6 \%)$ & $0(0 \%)$ & NS \\
\hline
\end{tabular}




\section{DISCUSSION}

Hand gripping causes an increased metabolism and oxygen consumption of the activated neurons. Neuronal function is coupled with increased regional cerebral blood flow ( $\mathrm{rCBF}$ ) related to metabolic demand, so-called vasoneuronal coupling [7]. When the autoregulatory vasodilatation and vasoconstriction are limited to small cortical vessels, the relationship between blood flow velocity and blood flow of the basal cerebral arteries is linear [8]. The changes in the diameter of these basal cerebral arteries can be neglected and therefore, relative blood flow changes in these arteries reflect the relative blood flow, as shown in studies using transcranial Doppler monitoring [9]. This physiological mechanism may be highly effective in providing needed blood flow.

In an earlier report, unilateral hand gripping was investigated [4]. BFV was found to increase $(11.3 \pm 4.9 \%)$ in 12 healthy subjects. Another study showed that BFV increased (17.6 $\pm 9.1 \%)$ during bilateral hand gripping in 16 healthy subjects [5]. In these studies, hand gripping was performed for 2 minutes. In our previous study, we used a different methodology [6] to prevent possible habituation which may occur when hand gripping continues for $2 \mathrm{~min}$. However, our previous results $(19.2 \pm 2.2 \%)$ were not different from those of earlier studies. In the present study, motor stimuli produced a marked increase in BFV in both MCAs in all subjects. Patients with lacunar infarction had nearly normal reactivity on both sides while patients with territorial infarction had lower reactivity on the lesion side compared to the nonlesion side or compared to patients with lacunar infarction or the control subjects. However, our results suggest that the motor cortex was activated bilaterally even if one hemisphere was involved to a greater or lesser degree.
In conclusion, we assessed the motor evoked proportional increases in blood flow velocities, reflecting blood flow according to the metabolic demand of the activated motor areas of both middle cerebral arteries using transcranial Doppler sonography which is a non-invasive and reproducible diagnostic tool. However, we had a relatively small sample size, and this test requires the cooperation of the subjects. Nevertheless, our results suggest that unilateral cerebrovascular ischemic events can affect blood flow in both MCAs in patients with acute ischemic events in the MCA territory, and neurovascular reactivity was preserved in patients with lacunar stroke in contrast to territorial stroke.

\section{REFERENCES}

1. Aaslid R. Visually evoked dynamic blood flow response of human cerebral circulation. Stroke. 1987; 18: 771-775.

2. Sortenberg W. Cerebral artery blood velocity and cerebral blood flow. In: Newell DW, Aaslid R, eds. Transcranial Doppler. New York, NY: Raven Press Publishers; 1992: 5766.

3. Aaslid R, Lindegaard KF, Sortenberg W, Nornes $H$. Cerebrovascular autoregulation dynamics in humans. Stroke. 1989; 20: 45-52.

4. Silvestrini M, Caltagirone C, Cupini LM, et al. Activation of healthy hemisphere in poststroke recovery. A transcranial Doppler study. Stroke 1993; 24: 1673-1677.

5. Stoll M, Seidel A, Schimrigk K, Hamann GF. Hand gripping and acetazolamide effect in normal persons and patients with carotid artery disease. J Neuroimag 1998; 8: 27-31.

6. Uzuner N, Yalcinbas O, Gucuyener D, Ozdemir G. Hand gripping effect on cerebral blood flow in normal subjects. European Journal of Ultrasound 2000; 11: 147-150.

7. Kuschinsky W. Coupling of blood flow and metabolism in the brain. J Basic Clin Physiol Pharmacol 1990; 1: 191-201.

8. Kirkham FJ, Padayachee TS, Parsons S, Seargant LS, House FR, Gosling RG. Transcranial measurement of blood velocities in the basal cerebral arteries using pulsed Doppler ultrasound: velocity as an index of flow. Ultrasound Med Biol. 1986; 12: 15-21.

9. Bishop CCR, Powell S, Rutt D, Browse NL. Transcranial Doppler measurement of middle cerebral arter blood flow velocity: a validation study. Stroke. 1986; 17: 913-915. 